\title{
Stachyurus praecox (Stachyuraceae), first report in Korea
}

\author{
Chan-Jin OH, Soon-Ho SHIN, Ji-Woong CHO, Hyoun-Woo KIM, Sang-Sub HAN ${ }^{1}$, \\ Ji-Won KIM ${ }^{2}$ and Jae-Min CHUNG $^{2 *}$ \\ Department of Forest Bio, Jeollannam-do Forest Resources Research Office, Naju 58213, Korea \\ ${ }^{\prime}$ Division of Forest Science, Chonbuk National University, Jeonju 54896, Korea \\ ${ }^{2}$ Division of Plant Resources, Korea National Arboretum, Yangpyeong 12519, Korea \\ (Received 9 November 2021; Revised 2 December 2021; Accepted 21 December 2021)
}

\begin{abstract}
We report a previously unrecorded woody species, Stachyurus praecox Siebold \& Zucc. (Stachyuraceae), in Korea. This species is considered to be endemic to Japan. Stachyurus praecox was collected for the first time in an evergreen forest on an uninhabited island of Bongsun-ri, Saengil-myeon, Wando-gun, Jeollanam-do in Korea. The inflorescence of the species was racemose and pendulous on the axils of the previous year's branches. Flowers bloomed from March to April. They were functionally dioecy but morphologically hermaphrodite. This woody species was named 'Wan-do-sul-kkot-na-mu' in Korean based on the shape of its inflorescence. Morphological characteristics and illustrations of this woody species have been provided with a distribution map and photographs of the natural habitat.
\end{abstract}

Keywords: first report in Korea, Stachyurus praecox, Stachyuraceae

Stachyuraceae J. G. Agardh, a family endemic to East Asia, is mainly distributed from the Himalayas across subtropical China to Taiwan Island and the Japan Archipelago (Feng et al., 2020). This family is comprised of a single genus, Stachyurus Siebold \& Zucc. with approximately 11 species, and consists of shrubs and small trees (Keiji, 1959; Feng et al., 2020). Su et al. (2020) redefined seven species of Stachyurus following an integrative species concept and revised the taxonomy of Stachyuraceae based on previous reports and specimens, including the type specimens.

Stachyurus praecox Siebold \& Zucc. has been regarded as an endemic species of Japan (Kitamura and Murata, 1994; Kato and Ebihara, 2011). This woody species is a pioneer shrub common in forest edges in the warm temperate zone in Japan (Abe, 2007). It is a small deciduous tree with single, alternate, and petiolate leaves (Keiji, 1959). Inflorescence is racemose, pendulous, located on axils of the previous year's branches, and $3-10 \mathrm{~cm}$ in length. The flowers are hermaphrodite or sometimes plant dioecious, with four each of sepals and petals (Abe, 2007). Fruit is a berry with a coriaceous pericarp that are broadly ellipsoid to ovoid, $0.7-1.2 \mathrm{~cm}$ in diameter, and green and brownish yellow when mature (Feng et al., 2020;
Su et al., 2020).

Recently, a natural population of the species was discovered on the uninhabited island of Wando-gun, Jollanam-do in Korea. This is the first report of S. praecox in a natural habitat in Korea. We provide the morphological characteristics, illustrations, photographs, and a distribution map of this woody species.

\section{Materials and Methods}

\section{DNA extraction}

Two accessions of $S$. praecox collected in Wando-gun were included in phylogenetic analysis. Voucher specimens (C. $J$. Oh OCJ80118 and OCJ80119) were deposited in the herbarium of Korea National Arboretum (KH). Specific informatin of the specimens are described in the Specimens examined section below. Total DNA from leaves was isolated using Exgene Plant SV (GeneAll Co., Seoul, Korea) following the manufacturer's protocol. Isolated DNA was stored at $-20^{\circ} \mathrm{C}$.

\section{Primer design and polymerase chain reaction}

PCR was performed using the internal transcribed spacer (ITS) 1 and ITS4 primers (White et al., 1990) for amplification

*Author for correspondence: rhuso@korea.kr 
of the ribosomal ITS regions. The PCR reactions were conducted with a final reaction volume of $30 \mu \mathrm{L}$ containing EmeraldAmp GT PCR Master Mix (Takara, Tokyo, Japan), each primer (10 pM) and template DNA (50-100 ng/ $\mu \mathrm{L})$.

The PCR reactions were carried out with an initial denaturation for $5 \mathrm{~min}$ at $94^{\circ} \mathrm{C}$, followed by 35 cycles of denaturation for 30 $\mathrm{s}$ at $96^{\circ} \mathrm{C}$, annealing for $30 \mathrm{~s}$ at $57^{\circ} \mathrm{C}$, extension for $1 \mathrm{~min}$ at $72^{\circ} \mathrm{C}$, and with a final extension for $10 \mathrm{~min}$ at $72^{\circ} \mathrm{C}$. PCR products were electrophoresed on a $1.5 \%$ agarose gel, and then the DNA band was confirmed using UV transilluminator. Amplified PCR products were purified using AccuPrep PCR Purification Kit (Bioneer Co., Daejeon, Korea), and sequenced using the same primers at Macrogen Co., Seoul, Korea

\section{Phylogenetic analysis}

To determine the phylogenetic position of newly collected plants in this study, we conducted maximum likelihood analysis using the nucleotide sequences of the ITS regions of six species of Stachyurus. Also, for phylogenetic analysis, Staphylea bumalda DC. (GenBank accession number: MH808363) was included as an outgroup. The newly obtained ITS sequences were edited by Geneious Prime (Kearse et al., 2012), and multiple sequence alignment was conducted by using the MAFFT program (Katoh, 2013). Maximum Likelihood analysis of the ITS data was performed in RAxML 8.2.11 (Stamatakis, 2006) with the following settings. Nucleotide model was used GTR-GAMMA; algorithm was used Rapid Bootstrapping and search for best-scoring maximum likelihood tree; the number of starting trees or bootstrap replicates were performed 100 times; and parsimony random seed was performed.

\section{Results and Discussion}

To determine whether the samples of Stachyurus collected from Wando-gun, Jeollanam-do are the same taxon as $S$. praexox, Maximum likelihood analysis based on the ITS dataset of regions of six taxa of Stachyurus was performed. The results suggested two accessions representing male and female plants collected on Wando-gun, denoted as "Stachyuruswando_Male" and "Stachyurus-wando_Female" formed a clade with $S$. praexox with strong bootstrap support (Fig. 1). Therefore, Stachyurus collected from Wando-gun, Jollanam-do in the present study was considered to be in the same taxon as $S$. praexox distributed in Japan. This is the first report not

Staphylea bumalda MH808363

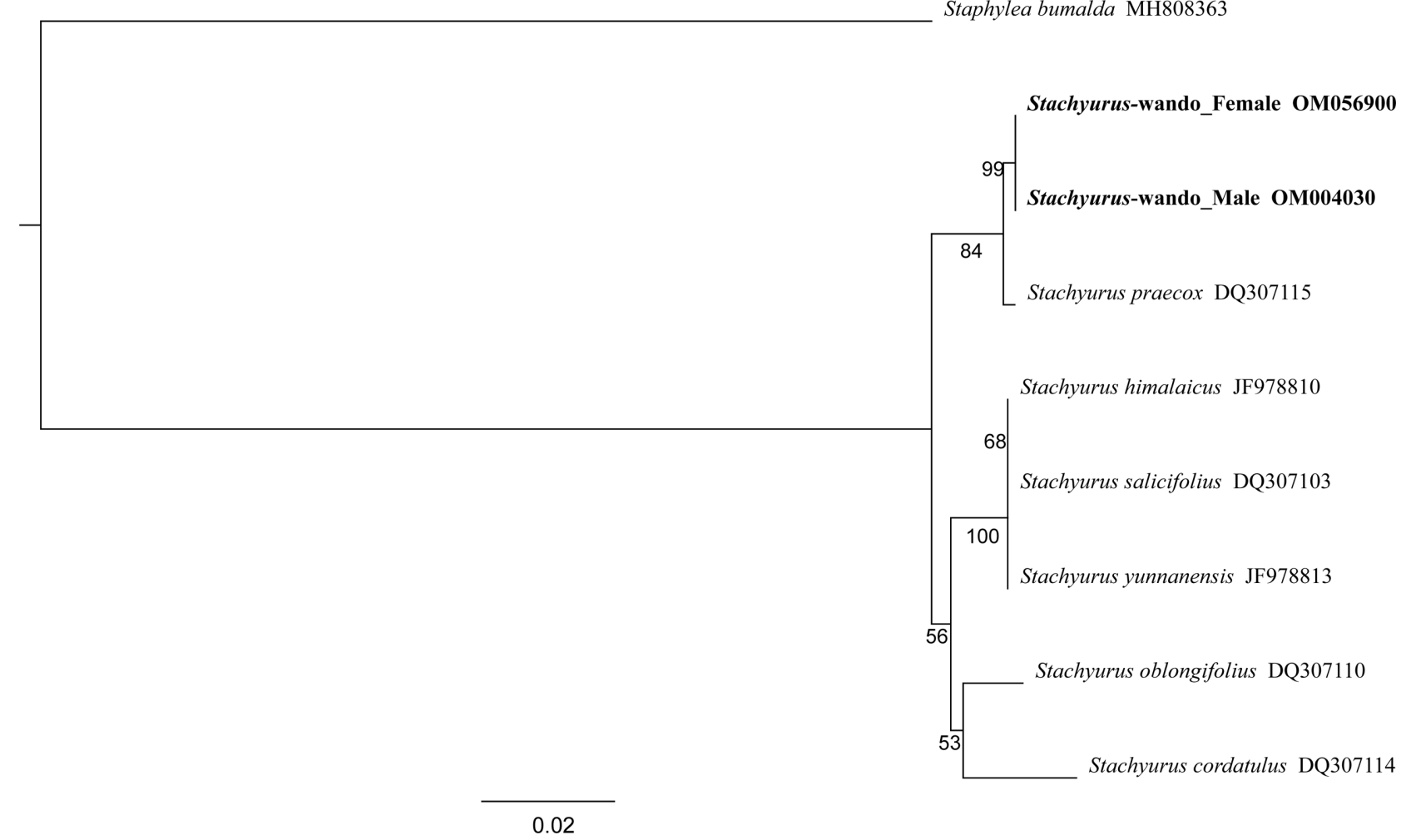

Fig. 1. Phylogenetic position of newly collected materials in Korea denoted with Stachyurus-wando from the analysis of nucleotide sequences from the internal transcribed spacer regions. The maximum likelihood tree is shown with bootstrap values above branches. GenBank accession number is indicated in each taxon. 
only of Stachyurus praecox in Korea but of Stachyuraceae in the Korean flora. We suggest Wan-do-sul-kkot-na-mu-gua (완 도술꽃나무과) for the Korean name of the family.

\section{Taxonomic Treatment}

Stachyurus praecox Siebold \& Zucc., Fl. Jap. (Siebold) 1: 43, 1836.

Stachyurus praecox var. rotundifolius Tuyama, J. Jap. Bot. 16: 504, 1940; S. praecox f. rotundifolius (Tuyama) Tuyama ex H. Hara, Enum. Sperm. Jap. 3. 229, 1954.

Stachyurus praecox var. microphyllus Nakai Bull. Nat. Sci. Mus. Tokyo no. 27: 31, 1949; S. praecox f. microphyllus (Nakai) H. Hara, Enum. Sperm. Jap. 3. 229, 1954.

Stachyurus praecox var. parviflous Makino ex H. Hara, Enum. Sperm. Jap. 3. 229, 1954.

Stachyurus praecox f. marginatus Hiyama, J. Jap. Bot. 36: 127, 1954.

Korean name: Wan-do-sul-kkot-na-mu (완도술꽃나무).

Deciduous usually small trees, stems 3-9 m tall, ca. 5-10 $\mathrm{cm}$ in diam., bark dull purplish-brown. Leaves alternate, petiole 1-3 cm long; blade chartaceous, usually elliptic to ovoid, 12-
$19 \times 5.5-8 \mathrm{~cm}$, apex acute to acuminate, base rounded to truncate, margins serrate, lower surfaces glabrous or sometimes pubescent on or along veins, lateral veins 5-7 pairs. Inflorescences racemose, pendulous, on axils of previous year's branches, $10-18 \mathrm{~cm}$ long (usually shorter in female); flowers functionally dioecious (but morphologically hermaphrodite), campanulate, 7-9 mm long; pedicel less than $0.5 \mathrm{~mm}$ long; bract triangular, $1.5-2 \mathrm{~mm}$ long; sepals 4; petals 4, greenish-yellow in pistillate flowers; stamens 8 , slightly shorter than petals, rudimentary in female flowers; pistil 1 , slightly longer than stamens in staminate flowers; ovary narrowly ovoid; style shorter than ovary. Fruit berry, broadly ellipsoid to narrowly ovoid, 8-10 $\mathrm{mm}$ in diam., green, brownish-yellow when mature. Seeds $80-105$ in a fruit, 1.5$3 \mathrm{~mm}$ long, 0.9-1.6 mm in diam., yellowish red (Figs. 2, 3).

Flowering: March to April.

Distribution: Korea (Wando-gun), Japan (Hokkaido, Honshu, Shikoku, Kyushu).

Specimens examined: KOREA. Jeollanam-do: Wando-gun, Saengil-myeon, Bongsun-ri, 4 Apr 2018, C. J. Oh OCJ80118, OCJ80119 (KH); 26 Mar 2021, C. J. Oh OCJ210088, OCJ210089, OCJ210090 (KH).

Stachyurus praecox was newly recorded from an inhabited island of Saengil-myeon, Wando-gun, Jeollanam-do in Korea
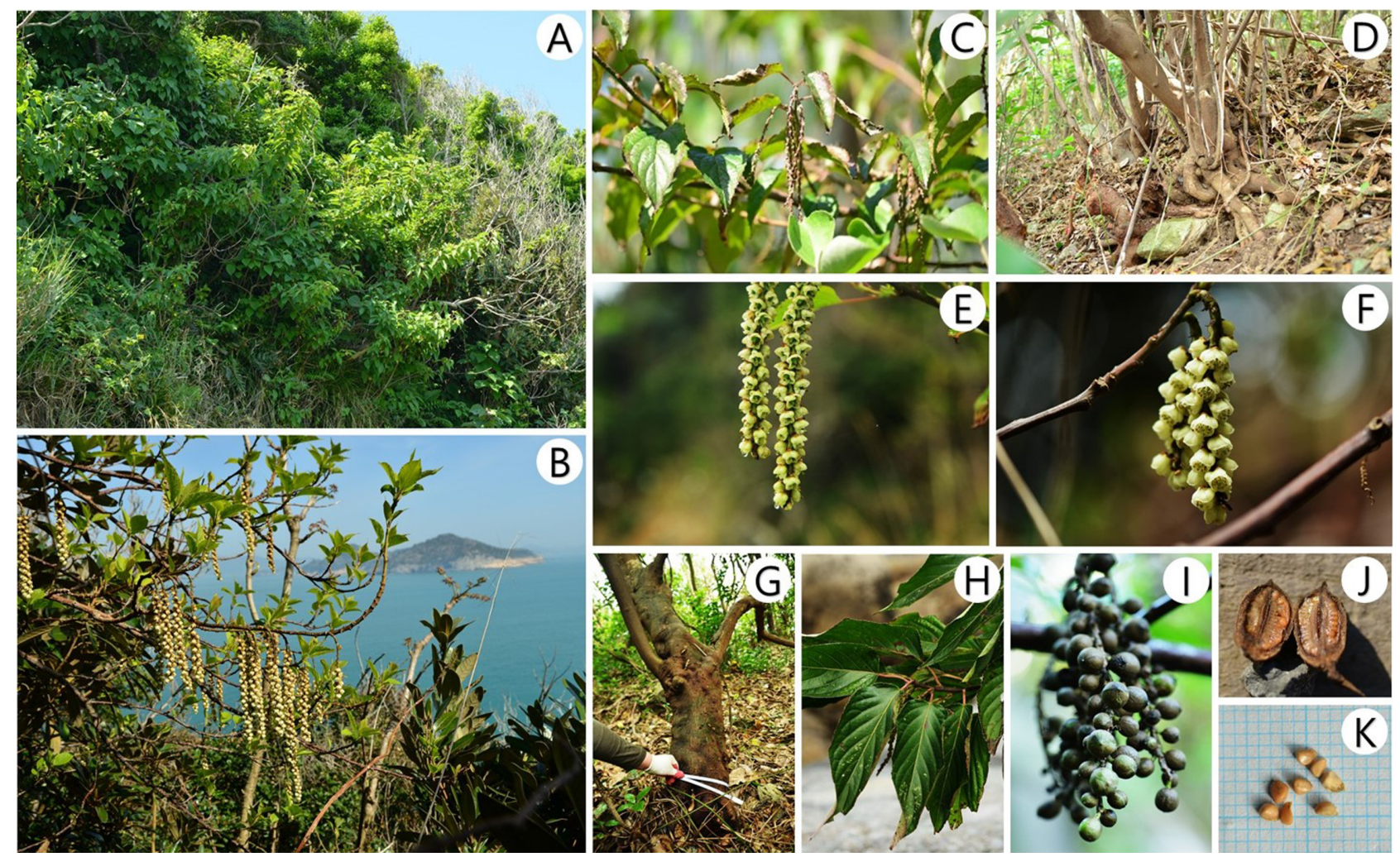

Fig. 2. Photographs of Stachyurus praecox Siebold \& Zucc. in Korea. A. Natural habitat. B. Flowering branch. C. Fruiting branch. D. Root collar. E. Female inflorescence. F. Male inflorescence. G. Diameter at basal height. H. Leaves. I. Fruits. J. Longitudinal section of fruit. K. Seeds. 


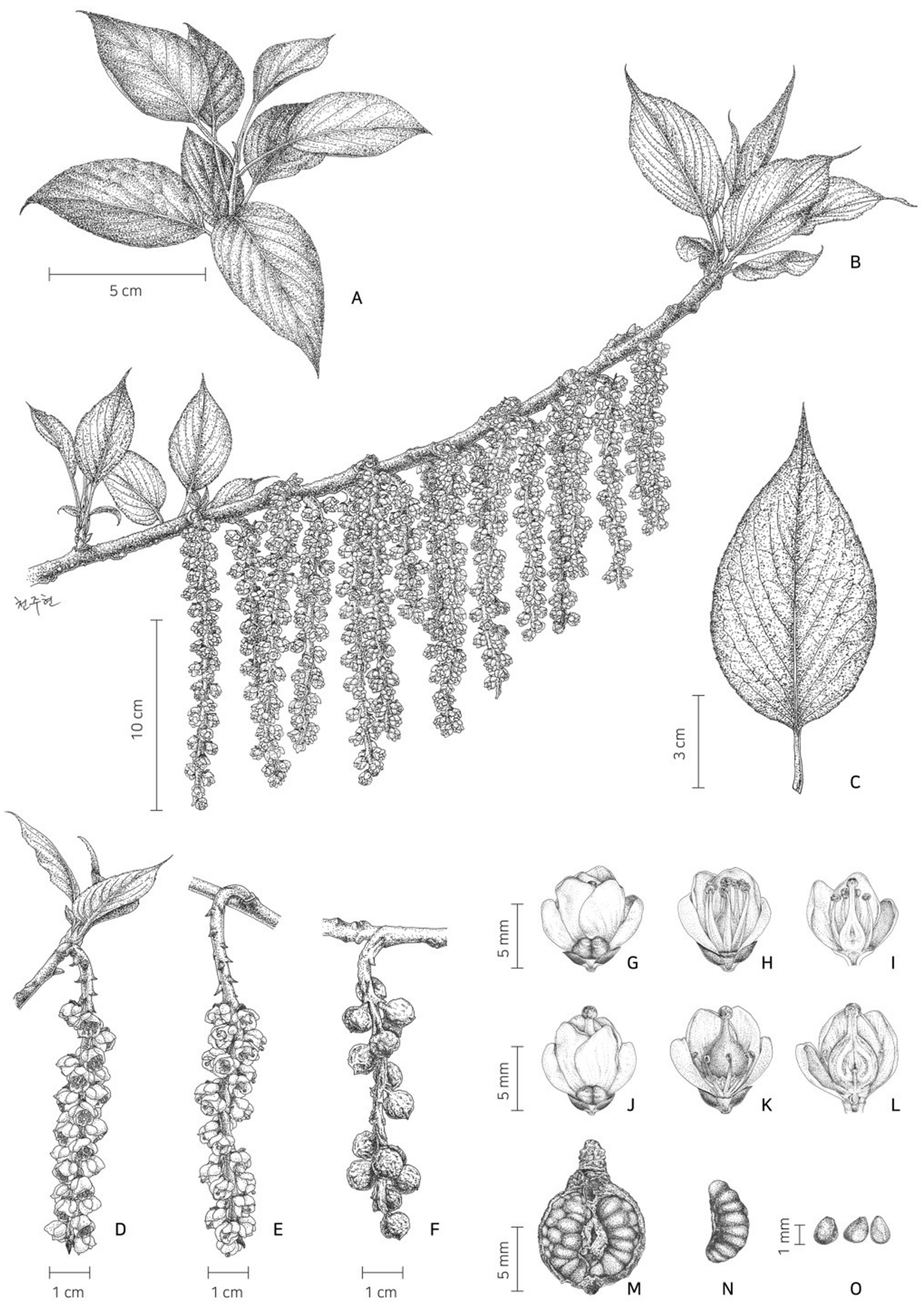

Fig. 3. Illustrations of Stachyurus praecox Siebold \& Zucc. A, B. Habit. C. Leaf. D. Male inflorescence. E. Female inflorescence. F. Fruits. G. Male flower. H. Stamens. I. Longitudinal section of male flower. J. Female flower. K. Pistil. L. Longitudinal section of female flower. M. Fruit. N. Arrangement of seed in fruit. $\mathbf{O}$. Seeds. 


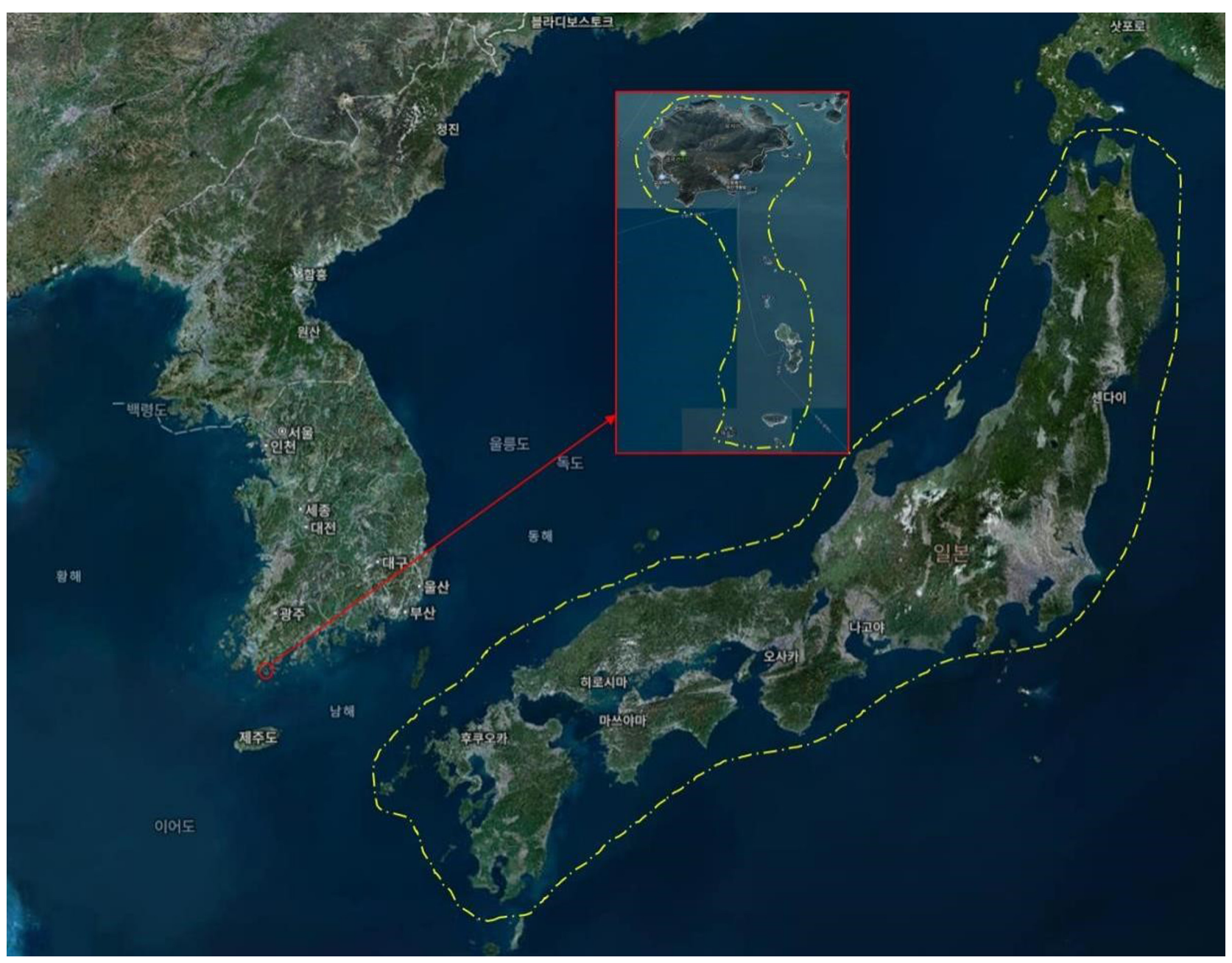

Fig. 4. Distribution map of Stachyurus praecox Siebold et Zucc. in Korea and Japan.

(Fig. 4). Over 200 trees were distributed along the coastline on the island. The tallest tree was $8 \mathrm{~m}$ high and $23 \mathrm{~cm}$ in basal diameter. Most of the trees had two to 6 branches (Fig. 2).

Stachyurus praecox, distributed in Wando-gun, Jeollanam-do in Korea, is presumed to have migrated approximately 40 to 50 years ago via bird dispersal of seeds that originated from Japan archipelago (Abe and Matsunaga, 2007; Sakai et al., 2010).

Vegetation analysis of the population showed that the tree layer was comprised of Neolitsea aciculata (Blume) Koidz. Dendropanax trifidus (Thunb.) Makino ex H. Hara and Ilex integra Thunb., and other species, and was dominated by Cinnamomum yabunikkei H. Ohba. In the subtree layer, $S$. praecox was the dominant species and Machilus thunbergii Siebold \& Zucc. ex Meisn., Ligustrum japonicum, Camellia japonica L., Litsea japonica (Thunb.) Juss., Ficus erecta Thunb., Neolitsea sericea (Blume) Koidz., Prunus serrulata Lindl. f. spontanea (E. H. Wilson) Chin S. Chang, Neolitsea aciculata (Blume) Koidz., and Eurya japonica Thunb. were the major species. The shrub layer was composed of Litsea japonica (Thunb.) Juss., Camellia japonica L., Dendropanax trifidus (Thunb.) Makino ex H. Hara, Stauntonia hexaphylla (Thunb.) Decne., Trachelospermum asiaticum (Siebold \& Zucc.) Nakai, Sinomenium acutum (Thunb.) Rehder \& E. H. Wilson, Hedera rhombea (Miq.) Siebold \& Zucc. ex Bean, $M$. thunbergii Siebold \& Zucc. ex Meisn., Osmanthus insularis Koidz., Aucuba japonica Thun, N. sericea (Blume) Koidz. and Callicarpa japonica Thunb., including S. praecox. The major species in the herb layer were Farfugium japonicum (L.) Kitam., Cyrtomium falcatum (L.f.) C. Presl, Ophiopogon jaburan (Siebold) Lodd., and Arisaema thunbergii Blume.

ORCID: Chan-Jin OH https://orcid.org/0000-0001-7582-6761; Soon-Ho SHIN https://orcid.org/0000-0002-6973-3515; Ji-Woong CHO https://orcid.org/0000-0002-5509-7183; Hyoun-Woo KIM https://orcid.org/0000-0002-8592-6405; Sang-Sub HAN https:// orcid.org/0000-0002-1162-3110; Ji-Won KIM https://orcid.org/ 
0000-0002-0599-3908, Jae-Min CHUNG https://orcid.org/00000002-2942-6641

\section{Acknowledgments}

We thank Dr. Jin-O Hyun, Prof. Seung-Chul Kim, Mr. Byeung-Yoon Park, Mr. Bong-Seok Kim, Miss Myeong-Ja Nam, Mr. Byeong-Hoon Min, and Mrs. Gyeong-Hee Lee for their help in providing the Korean name of 'Wan-do-sul-kkotna-mu' of S. praecox Sieb.

\section{Conflicts of Interest}

The authors declare that there are no conflicts of interest.

\section{Literature Cited}

Abe, T. 2007. Sex expression and reproductive biology of Stachyurus praecox (Stachyuraceae). Bulletin of FFPRI 6: $151-156$.

Abe, T. and M. Matsunaga. 2007. Germination characteristics of a pioneer shrub, Stachyurus praecox (Stachyuraceae). Bulletin of FFPRI 6: 145-149.

Feng, Y., H. P. Comes, Y.-X. Qiu. 2020. Phylogenomic insights into the temporal-spatial divergence history, evolution of leaf habit and hybridization in Stachyurus (Stachyuraceae). Molecular Phylogenetics and Evolution 150: 106878.

Kato, M. and A. Ebihara. 2011. Endemic Plants of Japan. The National Museum of Nature and Science. Tokai University Press, Kanagawa, 504 pp.

Katoh, S. 2013. MAFFT multiple sequence alignment software ver- sion 7: Improvements in performance and usability. (outlines version 7), Molecular Biology and Evolution 30: 772-780.

Kearse, M., R. Moir, A. Wilson, S. Stones-Havas, M. Cheung, S. Sturrock, S. Buxton, A. Cooper, S. Markowitz, C. Duran, T. Thierer, B. Ashton, P. Meintjes and A. Drummond. 2012. Geneious Basic: An integrated and extendable desktop software platform for the organization and analysis of sequence data, Bioinformatics 28: 1647-1649.

Keiji, U. 1959. Tree Encyclopedia, Vol. 3. Ariake Publisher, Tokyo, 1276 pp.

Kitamura, S. and G. Murata. 1994. Colored Illustrations of Woody Plants of Japan. Hoikusha Publishing Co., Ltd., Osakasa, 400 pp.

Sakai, A., T. Sakai, S. Kuramoto and S. Sato. 2010. Soil seed banks in a mature Hinoki (Chamaecyparis obtusa Endl.) plantation and initial process of secondary succession after clearcutting in southwestern Japan. Journal of Forest Research 15: 316-327.

Stamatakis, A. 2006. RAxML-VI-HPC: Maximum likelihoodbased phylogenetic analyses with thousands of taxa and mixed models, Bioinformatics 22: 2688-2690.

Su, J.-X., C.-C. Dong, Y.-T. Niu, L.-M. Lu, C. Xu, B. Liu, S.-L. Zhou, A.-M. Lu, Y.-P. Zhu, J. Wen and Z.-D. Chen. 2020. Molecular phylogeny and species delimitation of Stachyuraceae: Advocating a herbarium specimen-based phylogenomic approach in resolving species boundaries. Journal of Systematics and Evolution 58: 710-724.

White, T. J., T. Bruns, S. Lee and J. Taylor. 1990. Amplification and direct sequencing of fungal ribosomal RNA genes for phylogenetics, PCR Protocols: A Guide to Methods and Applications, Pp. 315-322.

\section{한국 미기록종 식물: 완도술꽃나무 (완도술꽃나무과) \\ 오찬진 · 신순호 - 조지웅 · 김현우 · 한상섭 ${ }^{1} \cdot$ 김지원 ${ }^{2} \cdot$ 정재민 $2^{*}$ \\ 전라남도 산림자원연구소 산림바이오과, '전북대학교 산림과학부, ${ }^{2}$ 국립수목원 식물자원연구과}

적 요: 전남 완도군 섬지역에서 발견된 Stachyurus praecox Siebold \& Zucc.를 우리나라 미기록 식물로 보고 한다. 이 수종은 일본의 난·온대지역에 넓게 분포하고 있으며, 특산수종으로 알려져 왔다. 꽃은 총상화서에 달리며, 형태적으로는 양성화지만, 기능적으로는 자웅이주로 관찰되었다. 화관은 흰색 또는 연한 보라색 꽃 잎과 꽃받침은 각각 4 개이다. 국명은 최초 발견지 지역명과 꽃차례 모양이 장식용으로 달리는 여러 가닥의 실을 의미하는 뜻으로 쓰이는 “술”을 고려하여 “완도술꽃나무”로 신칭하였으며, 이에 대한 기재문과 도해, 사진을 제시하였다.

주요어: 한국 미기록, 완도술꽃나무, 완도술꽃나무과 